\title{
Instructional Meaningfully Implementation in Distance Learning The Era of Pandemy Covid-19
}

\author{
Suhardin $^{1}$, Hayadin $^{2}$, Nurhayati $^{3}$ \\ \{suhardin@yahoo.com ${ }^{1}, \underline{\text { hayadin006@gmail.com }}$, nurhayatipauduntad@gmail.com ${ }^{3}$ \}
}

Universitas Ibnu Chaldun (UIC) Jakarta ${ }^{1}$, Pusat Penelitian dan Pengembangan (Puslitbang) Pendidikan Agama dan Keagamaan Balitbang Kemetrian Agama Republik Indonesia ${ }^{2}$, Universitas Tadulako ${ }^{3}$

\begin{abstract}
This article specifically proves that there are differences in the ability of students to explain verbally the meaning content with emphasize meaningfully and emphasize collaboration. The experiment research, by conducting two classes of learning on forty students. The data on the results of the students' ability to explain the contents of the letter Al-Jumuah verses 9-11 were analyzed with anova once or twice. The analysis resulted in the finding that there was a very significant difference in the students' ability to explain the contents of the verse. The concluded that contextual teaching learning which emphasizes meaningfully can have a very significant effect on students' ability to explain the content of the letter Al-Jumuah verses 911. The contextual teaching learning strategies that emphasize meaningfulness can be implemented in distance learning activities in the era of the Covid-19 pandemic.
\end{abstract}

Keyword : Meaningfully Instructional, Contextual Teacing Learning, Collaborative Learning, Distance Learning, Covid-19

\section{Introduction}

In the situation of the Corona Virus Diseases (Covid-19) pandemic, human activities are limited, so that the spread does not spread, the government has issued a policy in the form of large-scale social restrictions in order to accelerate the handling of Corona Virus Diseas2019 (COVID-19). Large-scale social restrictions include at least: a. school and work vacations; b. restrictions on religious activities; and / or c. restrictions on activities in public places or facilities. [1]. The school holidays referred to in the Perpres are, there are no activities at school, but they are carried out in their respective homes with a Distance Learning system.

This activity drains the teacher's energy to look for effective patterns and styles, so that learning runs smoothly, students can more quickly capture the messages conveyed by the teacher to him. Learning with the Distance Learning system requires teachers to be more active, creative, innovative, expressive, and persuasive in delivering learning material. The teacher begins learning by trying to design learning materials effectively, communicating interactively, stimulating children to learn literately, utilizing all available learning resources, both in virtual form and in the form of classical and modern references.

In classical learning in the classroom and outdoors, innovative learning patterns are in the form of active learning, [2] collaborative learning, [3] is effective in stimulating students' abilities, participation, and mastery of the material and learning delivered by the teacher. [4] In the situation of online learning with distance, it is more demanding for teachers to master the learning material to be delivered, the skills of teachers in efficiently packaging 
learning materials, the ability of teachers to deliver learning materials more communicatively and interactively in online standards, and The teacher's humanitarian efforts in greeting, individual and personal approach to students, so that students are more called to participate in learning and master the learning material delivered by the teacher.

Meaningful instructional, learning that provides students with a complete and thorough understanding of the learning material delivered by the teacher. But the problem is how and strategies to provide understanding to students in a learning atmosphere that is not physically facing. Learning is carried out from the teacher's house to each student's house, students take part in learning using handpond media with poor quality, teachers also generally have cellphones that are not too better than students. In an atmosphere that has these weaknesses and limitations, a teacher's struggle to learn to use learning strategies that can be meaningful to students is demanded, so that students do not fail to understand the learning material presented. Students' understanding of the learning material presented to them, makes them more enthusiastic about participating in learning, even harder to dig up information, looking for comments for learning resources. Conversely, if students do not understand the material makes them lazy, not eager to take part in learning.

Learning al-Qur'an and al-Hadith is a subject that requires deep understanding from students, so that there is no misunderstanding of the wrong contextualization. Al-Qur'an is full of meanings with multiple interpretations, as well as al-Hadith, which is full of meanings with multiple interpretations. The understanding that is inherent in students needs to be guided by the correct guidance, by choosing a valid, actual, and accountable reference. The valid, actual and usable references depart from the correct understanding of the texts. The understanding of the text departs from the depth of knowledge, understanding and investigation of the textual meaning of the verse, which is confirmed by several standard works. A person who learns about the verses of the Koran needs to justify the textual reading of the verse, the meaning of the textualization of the verse according to the mufradat, the translation of a verse based on the meaning of the mufradat, the interpretation of a verse based on the correct Arabic qaidah (grammar), the interpretation of several interpreters who their expertise has been tested, and the contextualization of the verse is in accordance with the developing social phenomena, and the ability to draw the connotative meaning of the verse as values that need to be practiced in human life and humanity. Doing all that requires learning that is full of meaning, meaningfully instructional, strategic steps to bring students to patterns, ways and strategies that are effective in learning. Strategic steps to create happy and enjoyable learning for students and teachers. Strategic steps to provide strengthening students' understanding of the concept of learning material conveyed by the teacher.

Teaching and Learning Contextual Teaching Learning (CTL) is defined as a way to introduce content using a variety of active learning techniques designed to help students relate what they already know to what is expected to learn, and to build new knowledge from analysis and synthesis. The theoretical basis for CTL is outlined, with a focus on Connection, Constructivist, and Active Learning theory. A summary of brain activity during the learning process describes the physiological changes and connections that occur during educational activities. Three types of learning scenarios (project-based, goal-based, and inquiry-oriented) are presented to illustrate how CTL can be practically applied.[5]

The offer and ammunition for a teacher to provide meaningfully learning to students, as conveyed by Hudson, is to apply a Contextual Teaching Learning (CTL) learning strategy. Where in this strategy, the teacher is guided to design student activities with active learning, students are required to be all active in doing something that has been designed by the teacher, the teacher must state that in the learning activities that are carried out all students are actively 
involved, no one is left behind and does not get assignments from the teacher. The teacher measures students' initial understanding of the learning presented, trying to connect students' initial understanding with the new understanding that will be conveyed by the teacher, so that continuity, connectivity of initial, new and future understandings appear in the students' brains. Teachers and students try to build a shared understanding of the conceptions of learning conveyed, contructivism, understanding and explanations of the learning that is conveyed built in the initiative and work of each student.

Contextual teaching and learning is a teaching-learning concept that helps teachers relate subject matter content to real-world situations; and motivate students to make connections between knowledge and its application in their lives as family members, citizens, and workers; and engage in the hard work it takes to learn. [6] learning should not be made by the teacher into an autophysical realm, but instead used as a real atmosphere by contextualizing the events experienced by conveyed learning, conveying learning with real examples experienced by students in everyday life. Mathematics teachers explain broadly with complex formulas, which will lead to student boredom, but mathematics teachers teach broadly by ordering students to calculate the area of the class they occupy, which will be very interesting and challenging for students. The religion teacher teaches students about life in heaven with the facilities of wine, honey and milk. When dealing with intelligent students who do not like milk, make them do not want to go to heaven because later they are forced to drink milk, this is certainly dangerous. Explain that heaven needs to ask students about each other's pleasures, and tell the children, the fun you experience is just a glimmer of pleasure in heaven. What food do you like and the most delicious, that food is only a bit of food that is in heaven. Heaven promises pleasures and pleasures that are much higher and greater than what we experience in the world. This is a concrete form of learning pattern that provides a complete and comprehensive understanding to students.

Contextual teaching learning (CTL) learning strategy is a learning strategy that stimulates students to analyze the contextualization of problems related to the concept being studied. The Integrative Learning Strategy is a strategy for linking several learning concepts and trying to construct and formulate understanding related to new concepts being studied. [7] The two strategies above CTL and IL attempt to build a complete, solid, strong, integrated understanding of students in student thinking, so that they are motivated, encouraged, challenged, to dig more critically about the problems presented by the teacher as their learning. The important point of all this is the hard work of the teacher to concoct, crochet, sew and present interesting lessons. This can be done with the creativity of the teacher. Teachers who are active, will not lose their minds to make this all, but teachers who are not creative, will be lazy, sulk, angry, surrender and give up.

Besides meaningfully, learning that will be able to provide happiness to students is collaboration, collaborative learning, bringing together all the potential, abilities, advantages, each student in a togetherness, to achieve common goals, understand, understand and master the learning delivered by the teacher, so that not a single student is left behind. Solidarity, togetherness, and solidarity are the basis for learning designs designed by teachers in managing learning activities both in real classrooms and virtual classrooms (distance learning).

Collaborative learning describes a situation in which two or more subjects build a synchronous and interactive joint solution to some problem. This difference places more emphasis on the level and quality of exchanges that occur within groups of students in a collaborative environment.[8] Marriage between subjects and full student participation is the basis for planning this collaborative learning strategy. There are no subjects that stand alone 
perpendicular to today's global problems, but all are interrelated and help each other to build a broad and deep understanding of students. The level of students' understanding of the problems being studied will affect their insights, attitudes, and actions.

In collaborative learning, learner-centered rather than teacher-centered instruction and knowledge is seen as a social construct, facilitated by peer interaction, evaluation and cooperation. Therefore, the role of the teacher changes from transferring knowledge to students to being a facilitator in the construction of students' own knowledge. Some examples of collaborative learning activities are seminar-style presentations and discussions, debates, group projects, simulations and role-playing exercises, and the collaborative composition of essays, exam questions, research stories or plans. This new conception of learning shifts the focus from teacher-student interactions to the role of peer relations to achieve success in learning. [9] The teacher changes his / her figure from being the wisest, most understanding, most understanding, personal who is the center of information turning into a facilitator who provides a place and atmosphere for students to share, interact, participate in solving learning problems which he is currently working on. The teacher changes status from a resource person to a class manager. He manages class management, mediates several views, opinions and interruptions from each student. Also hosting in distance learning.

Collaborative learning is an educational approach to teaching and learning that involves groups of students working together to solve problems, complete assignments, or create products. [10] The teacher as a managerial, organizes students to work together, all individuals in the group play a role, participate, are active, creative, in completing something that has been projected by the teacher. Learning in a collaborative style provides social, psychological, academic and assessment benefits. All of them bring joy and happiness to students in participating in learning.

Collaboration is a philosophy of interaction and a personal lifestyle in which individuals are responsible for their own actions, including learning and respecting the abilities and contributions of their peers. In all situations where people gather in groups, this suggests ways of dealing with people that are respectful and highlights the abilities and contributions of each group member. [11] The essence emphasizes tolerance, solidarity, respect and cooperation in solving a problem assigned to the group. Group success is not individual success. The greatness of the individual dissolves in the greatness of working together in a group. This strategy apart from creating individual abilities, also sharpens solidarity, tolerance and respect for other individual abilities inside and outside the work group.

In this research experiment, the researcher attempted to see the differences in students' abilities in explaining the meaning of the letter Al-Jumuah verses 9-11 in two learning strategies carried out online, online, and by distance learning. Contextual teaching learning emphasizes meaningfully by taking contextual strategy steps. Collaborative learning emphasizes togetherness and integration with other subjects, carrying out collaborative steps. In the end, the students got the scores for the students' ability to describe the meaning of alQur'an surah al-Jumuah verses 9-11 orally by showing a five-minute video. Are there differences in students' abilities using different learning strategies on the same topic, the same quality of students, the same learning media, and the same teacher skills.

\section{Methodology.}

This research is quantitative with an experimental method, [12] using a comparational pattern in two experimental classes. The first class in Distance Learning is 
implemented by Contextual Teaching Learning. Second class in Distance Learning Collaborative Learning. Both of these methods pursue the learning outcomes of students' abilities in explaining (mensharah) the meaning of the al-Qur'an verse in surah al-Jumuah verses 9-11.

The design can be described as follows:

Tabel: 1. Experiment Research Desain

\begin{tabular}{lcc}
\hline & \multicolumn{2}{c}{ Instructional Strategy } \\
\cline { 2 - 3 } & CTL & Colaborative Learning \\
\hline $\begin{array}{l}\text { The ability of students to explain the meaning } \\
\text { of QS Al-Jumuah: 9-1 }\end{array}$ & $\geq$ \\
\hline
\end{tabular}

Ability to explain the meaning content with indicators; (1) explain the mufradat meaning of the verse; (2) asbabun nuzul ayat; (3) the meaning contained in the verse; (4) contextualization of the verse in the present life; (5) the value that can be learned from the paragraph.

The Contextual Teaching Learning method is carried out by teachers in the following stages: (1) developing the idea that children will learn more meaningfully by working on their own, discovering themselves, and constructing their own knowledge and other skills; (2) develop students' curiosity by asking questions; (3) creating a learning society; (4) presenting a model as an example of learning; (5) reflecting at the end of the meeting; (6) carry out the actual assessment in various ways. In the collaborative learning method, the activities carried out by the teacher: (1) convey learning objectives and motivate students; (2) present information; (3) organize students into groups; (4) guiding the work and study groups; (5) provide evaluation; (6) give awards. All teacher orders are carried out online using the google class room platform, zoom meting, whatsap group.

The teacher learns al-Qur'an Hadith with learning materials of al-Qur'an surah AlJumuah (62): 9-11; By implementing a learning pattern in the first class, subject teachers with PAI undergraduate qualifications at universities that have been institutionally accredited in Jakarta and have been certified to carry out learning with the Contextual Teaching Learning strategy, with the google class room platform, zoom meting, whatsap group. The second class is taught by subject teachers with undergraduate qualifications of PAI at an institutionally accredited university in Jakarta and has been certified to carry out learning with the Collaborative Learning strategy, with the google class room platform, zoom meting, whatsap group. The learning was conducted in two meetings and the third meeting was carried out by taking students' scores with individual practice with a duration of five minutes.

From taking the values of the two experimental classes, the researcher tried to analyze the data, by doing description analysis and infrential analysis. [13] In descriptive analysis, the researcher presents a data description; sum, mean, mode, variance, standard deviation, range, maximum, minimum, in the two experimental classes (CTL class and CL class). [14] After completing the description analysis the researcher carried out the requirements for the infrential analysis by testing the normality of the data of the two learning classes, testing the homogeneity of the two classes and after that was all done, the researcher conducted an infrential test by making comparisons between the CTL and CL classes using the t-test (difference test) and test. [15] the significance of the differences between the two experimental classes. 


\section{Discussion and Result.}

From the results of the assessment carried out in the first class that applied the Contextual Teaching Learning learning strategy, the scoring obtained from twenty students was as follows: mean 86.25 (eighty six point twenty five), standard error of mean 1.6 (one point six), median 90 (ninety), mode 90 (ninety) standard deviation 7,23 (seven point twenty three), variance 52,30 (fifty two point thirty), range 30 (thirty), minimum 65 (sixty five), maximum 95 (ninety five) and a total value of 1,725 (one thousand seven hundred and twenty five)

The data description can be visualized in a histogram as follows:

Tabel: 2. Histogram of Learning Result Data With CTL

\begin{tabular}{lccclll}
\hline Number & $\begin{array}{c}\text { Interval } \\
\text { Class }\end{array}$ & $\begin{array}{c}\text { Lower } \\
\text { Limit }\end{array}$ & $\begin{array}{c}\text { Upp;er } \\
\text { Limit }\end{array}$ & $\begin{array}{c}\text { Absolute } \\
\text { Frequency }\end{array}$ & $\begin{array}{c}\text { Relativly } \\
\text { Frequency }\end{array}$ & $\begin{array}{c}\text { Cumulativly } \\
\text { Frequency }\end{array}$ \\
\hline 1 & $64-70$ & 63,5 & 70,5 & 1 & $5 \%$ & $5 \%$ \\
\hline 2 & $71-77$ & 70,5 & 77,5 & 0 & $0 \%$ & $5 \%$ \\
\hline 3 & $78-84$ & 77,5 & 84,5 & 5 & $25 \%$ & $30 \%$ \\
\hline 4 & $85-91$ & 84,5 & 91,5 & 11 & $55 \%$ & $85 \%$ \\
\hline 5 & $92-98$ & 91,5 & 98,5 & 3 & $15 \%$ & $100 \%$ \\
\hline
\end{tabular}

From the results of the assessment carried out in the second class that implements the Collaborative Learning learning strategy, the scores obtained from twenty students are as follows: mean 69.75 (sixty-nine point seven five), standard error of mean 3.2 (three point two), median 70 (seventy), mode 70 (seventy) standard deviation 14.27 (fourteen point twenty seven), variance 203.88 (two hundred three point eight eight), range 55 (fifty five), minimum 40 (forty), maximum 95 (ninety five) and a total value of 1.395 (one thousand three hundred and ninety five)

The data description can be visualized in a histogram as follows:

Tabel: 3. Histogram of Learning Result Data With CL

\begin{tabular}{lcccccc}
\hline \multirow{2}{*}{ Number } & $\begin{array}{c}\text { Interval } \\
\text { Class }\end{array}$ & $\begin{array}{c}\text { Lower } \\
\text { Limit }\end{array}$ & $\begin{array}{c}\text { Upp;er } \\
\text { Limit }\end{array}$ & $\begin{array}{c}\text { Absolute } \\
\text { Frequency }\end{array}$ & $\begin{array}{c}\text { Relativly } \\
\text { Frequency }\end{array}$ & $\begin{array}{c}\text { Cumulativly } \\
\text { Frequency }\end{array}$ \\
\hline 1 & $39-50$ & 38,5 & 50,5 & 2 & $10 \%$ & $10 \%$ \\
\hline 2 & $51-62$ & 50,5 & 62,5 & 4 & $20 \%$ & $30 \%$ \\
\hline
\end{tabular}




\begin{tabular}{lllllll}
\hline 3 & $63-74$ & 62,5 & 74,5 & 6 & $30 \%$ & $60 \%$ \\
\hline 4 & $75-86$ & 74,5 & 86,5 & 7 & $35 \%$ & $95 \%$ \\
\hline 5 & $87-98$ & 86,5 & 98,5 & 1 & $5 \%$ & $100 \%$ \\
\hline & Sum & & & 20 & $100 \%$ & \\
\hline
\end{tabular}

Before conducting a different test analysis, the researcher carried out the requirements analysis by testing the normality of the data in each group. In the KolmogoroveSmirnove normality test, [16] the results of the student's ability to explain the verses of the AlQur'an surah Al-Jumuah verses 9-11 in the data group with the normal Contextual Teaching Learning strategy were obtained by obtaining asymp sign data of $0.171>0.05$ and the results of the student's ability to explain Al-Qur'an verses, surah Al-Jumuah verses 9-11 in the data group with the normal Collaborative Learning strategy with asymp sign data acquisition of $0.708>0.05$. Thus the two data groups were normally distributed.

Levene's test for equality of variances in order to test the similarity of variances between groups of data on the results of students' ability to explain the verses of the Al-Qur'an surah Al-Jumuah verses 9-11 in the data group of students who were taught with the Cotextual Teaching Learning strategy and the data group results of student abilities explaining the verses of the Al-Qur'an surah Al-Jumuah verses 9-11 in the data group of students who are taught with collaborative learning, it is obtained a significance of $0.025<0.05$, it can be concluded that the student data in the CTL group and the collaborative learning strategy have different variants.

In the t-test for equality of means, testing the differences between the two groups of data results from the student's ability to explain the verses of the Qur'an, surah Al-Jumuah verses 911 in the data group of students who are taught with the Cotextual Teaching Learning strategy and the result data group The ability of students to explain the verses of the Al-Qur'an surah Al-Jumuah verses 9-11 in the data group of students who were taught with collaborative learning obtained a significance result of $0.00<0.01 * *$ the conclusion is that there is a very significant difference in the results of student ability explain the verses of the Al-Qur'an surah Al-Jumuah verses 9-11 to the data group of students who are taught with the Cotextual Teaching Learning strategy and the data group results of the student's ability to explain the verses of the Qur'an, surah Al-Jumuah verses 9-11 in the group student data that students are taught with collaborative learning. From these results it can be stated that there is a significant effect of Contextual Teaching Learning learning strategies on students' ability to explain the verses of Al-Qur'an surah Al-Jumuah verses 9-11 with a distance learning pattern which was implemented during the Covid-19 pandemic.

From the results of the above research it can be seen that the ability of students to explain the meaning content of the verses of the Koran surah al-Jumuah verses 9-11 between those taught by the teacher with a contextual teaching learning strategy approach and those taught by the teacher with a collaborative learning strategy approach. different. Students who are taught with contextual teaching learning have a higher ability to explain the meaning content of the verses of al-Qur'an surah al-Jumuah verses 9-11 compared to those taught with a collaborative learning strategy approach. Thus the researcher concluded that the contextual teaching learning strategy had a significant effect on the students' ability to explain the meaning of the verses of the Qur'an, surah al-Jumuah verses 9-11, so in learning conducted by teachers online through distance learning, it is recommended to take this approach. contextual teaching learning strategies.

The contextual teaching learning strategy emphasizes learning meningfully based students. The teacher designs meaningful learning to students in a real sense. The meaning of 
this learning can at least be seen in several ways. First, the construction of learning materials directed by the teacher builds the essence of meaning. The teacher guides and directs students to construct a discussion or variable by studying the theory associated with the conception of the variable, linking it with other variables, which have theoretical relationships, so that students are challenged to have a wealth of vast and deep knowledge of the problems being taught. The learning materials were explored by students from various sources, both in the form of standard references, journals found on the internet, and reading books available in the school library.

Second, the teacher and students try to contextualize the learning material that is discussed, studied, and discussed in relation to actual problems that develop in the midst of society, experienced by students. So that with this, students become human beings who live and care about the real life that occurs in their surroundings, not becoming a person who is separated from their environment. He lives in the middle of the environment, understands the environment, responds to various problems in his environment with theoretical studies that he is studying in school with his friends and teachers.

Third, the learning event gives a deep impression and meaning to each individual student, because students are given personal assignments and responsibilities, given group responsibility, and given collective responsibility. The tasks, functions and roles of individuals, groups and collectivities become strategic momentum for students in the life and learning history that they are currently undergoing. This event is meaningful in the history of learning that he went through for one semester, one year and during his studies at certain institutions.

Fourth, learning is designed in the context of togetherness and individual competition, groups in a collective family. Each individual student competes in true goodness to his friends. Kindness given to friends becomes individual satisfaction for a student, he feels the meaning of himself doing good to his friends. The more he gives kindness to his friends, the more meaningful he feels to his friends. Learning becomes something fun and has its own meaning for individual students. He does not feel that he is being the object of a teacher, the target of exploitation of a teacher, but is made a friend, a teacher partner in learning.

Fifth, learning is carried out happily, joyfully and happily, so that the learning atmosphere is more meaningful in students and teachers than in a myriad of other activities outside of learning. Meaningfully Instructional in the end bring thingkingfully, students are trained to think critically, deeply, systematically and integratively, enjoyingfully, all who are involved in learning, students, teachers and education staff enjoy a memorable and deep meaningful learning atmosphere.

Five important points that researchers analyzed from the research findings became the strengthening of the argument for the massive and consistent application of contextual teaching learning with an emphasis on meningfully in distance learning in the atmosphere of the Covid-19 pandemic. Because this has been proven empirically and can be justified scientifically. For the follow-up, research is needed related to the development of certain subject models using the contextual teaching learning strategy that emphasizes meaningfully.

\section{Conclution and Recomendation.}

From the results of the research and discussion above, it can be concluded that contextual teaching learning strategies that emphasize meningfully instructional have a very significant effect in building students' abilities to explain the meaning content of al-Qur'an 
surah al-Jumuah verses 9-11. So thus that the contextual teaching learning strategy needs to be implemented by teachers in distance learning in the midst of the Covid-19 pandemic.

For the application of contextual teaching learning in certain subjects, the teacher needs to change the learning paradigm from transformational learning to meaningful learning by creating a positive and deep impression on learning that will be carried out both in a distance learning atmosphere and in classical learning indoors and outdoors. The teacher designs the momentum of learning as a monumental atmosphere for all parties, so that it has a deep and historical meaning for individual students, student groups and student collectivity. This monumental and historical impression will be awakened in the individual self of students, student groups, and student collectivity, by giving assignments, functions and responsibilities to individuals, groups and collectivities of students, so that this becomes self-achievement, self-satisfaction, and their own history. on individuals, groups and collectivities.

\section{References}

[1] Presiden Republik Indonesia, "Peraturan Pemerintah Nomor 21 Tahun 2020 tentang Pembatasan Sosial Berskala Besar Dalam Rangka Percepatan Penanganan Coronavirus Disease 2019/COVID19," vol. 2019, no. 022868, p. 8, 2020.

[2] A. Sastria and A. Muhammad, "Perbandingan Metode Pembelajaran Active Learning," vol. 7, 2018.

[3] H. Zaini, "Strategi Pembelajaran Aktif," Semin. Lokakarya Nas. Pendidik. Biol. FKIP UNS, pp. 19, 2009.

[4] S. Suhardin and E. Purnomo, "PENGARUH STRATEGI PEMBELAJARAN PROBLEM BASED LEARNING DENGAN PENDEKATAN PEMBELAJARAN KONTEKSTUAL DAN PENDEKATAN KULIAH TERHADAP KEPEDULIAN LINGKUNGAN DAN PENGUASAAN KONSEP DASAR EKOLOGI," Muqaddimah J. Stud. Islam, vol. 14, no. 3, pp. 78-101, 2018.

[5] C. C. Hudson and V. R. Whisler, "Contextual teaching and learning for practitioners," IMSCI 2007 - Int. Multi-Conference Soc. Cybern. Informatics, Proc., vol. 2, no. 4, pp. 228-232, 2007.

[6] R. G. Berns and P. M. Erickson, Contextual teaching and learning: Preparing students for the new economy, vol. 5. Citeseer, 2001.

[7] S. Suhardin, "Pengaruh Strategi Pembelajaran Contextual Teaching Learning Dan Integreted Instructional Terhadap Kemampuan Berpikir Kritis Siswa Tentang Zakat," EDUKASI J. Penelit. Pendidik. Agama dan Keagamaan, vol. 16, no. 2, pp. 124-137, 2018, doi: 10.32729/edukasi.v16i2.463.

[8] D. D. Curtis and M. J. Lawson, "Exploring collaborative online learning," J. Asynchronous Learn. Netw., vol. 5, no. 1, pp. 21-34, 2001, doi: 10.24059/olj.v5i1.1885.

[9] S. Roxanne and S. R. Hiltz, "Collaboratwe Learning in Asynchronous Learning," WebNet 98 World Conf. WWW, Internet, Intranet Proc. (3rd, 1998.

[10] M. Laal and S. M. Ghodsi, "Benefits of collaborative learning," Procedia - Soc. Behav. Sci., vol. 31, no. 2011, pp. 486-490, 2012, doi: 10.1016/j.sbspro.2011.12.091.

[11] L. Brown and V. Lara, "Professional development module on collaborative learning," El Paso Community Coll. Texas USA. Retrieved Jan, vol. 5, p. 2012, 2011.

[12] D. Ary, "An Invitation to Research in Social Education," Beverly Hills Sage Publ., 2002.

[13] D. C. Montgomery, Design and Analysis of Experiments, Ke-10. New York: Wiley \& Sons, 2001.

[14] S. Dowdy, S. Wearden, and D. Chilko, Statistics for Research, The firt. Canada: Willey, 2004.

[15] Suwanda, Desain Eksperimen untuk Penelitian Ilmiah, Pertama. Bandung: Alfabeta, 2011.

[16] J. R. F. Norman E. Wallen, Educational Research A Guide to the process, Pertama. London: Lawrence Erbaum Associate, 2001. 